\title{
Heterotopic Pancreatic Tissue of the Stomach: Report of Three Cases and Consideration of Its Histogenesis
}

\author{
Tadashi Terada \\ Department of Pathology, Shizuoka City Shimizu Hospital, Shizuoka, Japan
}

\section{Key Words}

Stomach $\cdot$ Heterotopic pancreatic tissue $\cdot$ Histogenesis

\begin{abstract}
Heterotopic pancreatic tissue of the stomach is a rare condition. The author herein reports three cases of heterotopic pancreatic of the stomach. The three cases were found in the 8,154 gastric specimens (biopsy 6,122 cases, gastrectomy 2,032 cases) of our pathology laboratory; the frequency was $0.04 \%$. The first case was a 57 -year-old woman who presented with epigastralgia. Endoscopic examination revealed a submucosal tumor in the body of the stomach. Partial gastrectomy was performed. Histologically, the lesion measured $25 \times 20 \times 25 \mathrm{~mm}$ and was submucosal heterotopic pancreatic tissue with hemorrhage and cystic changes. It was composed of acinar cells, ducts, and islets (Heinrich type I). The second case was a 57-year-old man without symptoms. Endoscopic examination revealed a submucosal tumor, and biopsy was taken. The biopsy showed heterotopic pancreatic tissue in the mucosa. It consisted of acinar cells and ducts (Heinrich type II). The third case was a 54-year-old woman without symptoms. Endoscopic examination showed chronic gastritis, and biopsy was obtained. The biopsy revealed heterotopic pancreatic tissue in the mucosa. It consisted of acinar cells and ducts (Heinrich type II). The first case appears to be a true heterotopic pancreas of congenital abnormality. The second and third cases seem to be heterotopic pancreatic tissues of congenital anomaly of the gastric mucosa. The histogenesis of heterotopic pancreatic tissue is discussed.
\end{abstract}

\section{Introduction}

Heterotopic pancreatic tissue is rare and occurs in the stomach, duodenum, ileum, common bile duct, Meckel's diverticulum, and the liver [1,2]. Recently, several case reports of heterotopic pancreas of the stomach have been published in the English language literature [3-7]. However, heterotopic pancreas of the stomach was already 


\begin{tabular}{r|l|l|l}
$\begin{array}{r}\text { Case Reports in } \\
\text { Gastruenterology }\end{array}$ & $\begin{array}{l}\text { Case Rep Gastroenterol 2010;4:386-392 } \\
\text { DOI: 10.1159/000320676 }\end{array}$ & $\begin{array}{l}\text { Published online: } \\
\text { September 18, 2010 }\end{array}$ & $\begin{array}{l}\text { O 2010 S. Karger AG, Basel } \\
\text { ISSN 1662-0631 } \\
\text { www.karger.com/crg }\end{array}$ \\
\hline
\end{tabular}

studied in a very large series by Yamagiwa et al. $[8,9]$. They examined the whole stomach by numerous sections in gastrectomies. They showed 107 cases of heterotopic pancreas out of 5,446 surgically resected stomachs; the incidence was $1.2 \%$ [8]. They also found cystic changes of heterotopic pancreas of the stomach in $6 \%$ [8]. The author herein reports three cases of heterotopic pancreatic tissue found in 8,154 consecutive gastric pathologic specimens.

\section{Materials and Methods}

The author reviewed 8,154 consecutive pathologic specimens (biopsy 6,122 cases, gastrectomy 2,032 cases) of the stomach in our pathology laboratory in search for heterotopic pancreatic tissue. In almost all of the gastrectomy specimens, tissue was examined only in and proximal to the distal margins. In cases with heterotopic pancreatic tissue, an immunohistochemical study was performed usint the Dako Envision method (Dako Corp., Glostrup, Denmark) for p53 protein (DO-7, Dako) and Ki-67 antigen (MIB1, Dako), as previously described [10-13].

\section{Results}

Three cases with heterotopic pancreatic tissue of the stomach were found in the 8,154 gastric specimens; the frequency was $0.04 \%$. Gastric mucosa of endoscopically suspected heterotopic pancreas almost always did not reveal the heterotopic pancreatic tissue, because the biopsy specimens contained only mucosa; heterotopic pancreas is a submucosal lesion.

The first case was a 57-year-old woman who presented with epigastralgia. Endoscopic examination revealed a hemorrhagic submucosal tumor in the body of the stomach. Partial gastrectomy was performed under the clinical diagnosis of gastric carcinoma or submucosal tumor. Grossly, the stomach showed a hemorrhagic and cystic submucosal tumor measuring $25 \times 20 \times 25 \mathrm{~mm}$ in the body of the stomach (fig. 1a). Histologically, the lesion was submucosal heterotopic pancreatic tissue with hemorrhage and cystic changes (fig. 1b). It was composed of acinar cells, ducts, and islets (Heinrich type I) (fig. 1c). Immunohistochemically, the pancreatic tissue was negative for p53 and Ki-67 labeling was $0.5 \%$.

The second case was a 57-year-old healthy man without symptoms. Endoscopic examination was performed as a routine examination, and it revealed a submucosal tumor measuring $10 \times 12 \times 14 \mathrm{~mm}$. A biopsy was taken. The biopsy showed heterotopic pancreatic tissue in the mucosa (fig. 2a). It consisted of acinar cells and ducts (Heinrich type II) and was free of islets (fig. 2b). Immunohistochemically, the pancreatic tissue was negative for p53 and Ki-67 labeling was 1.2\%.

The third case was a 54-year-old woman without symptoms. Endoscopic examination was performed as a routine examination. It showed chronic gastritis, and biopsy was obtained. The biopsy revealed heterotopic pancreatic tissue in the mucosa (fig. 3a). It consisted of acinar cells and ducts (Heinrich type II) and was devoid of Langerhans islets (fig. 3b). Immunohistochemically, the pancreatic tissue was negative for p53 and Ki-67 labeling was $0.2 \%$. 


\begin{tabular}{r|l|l|l}
$\begin{array}{c}\text { Case Reports in } \\
\text { Gastroenterology }\end{array}$ & $\begin{array}{l}\text { Case Rep Gastroenterol 2010;4:386-392 } \\
\text { DOI: 10.1159/000320676 }\end{array}$ & $\begin{array}{l}\text { Published online: } \\
\text { September 18, 2010 }\end{array}$ & $\begin{array}{l}\text { O 2010 S. Karger AG, Basel } \\
\text { ISSN 1662-0631 } \\
\text { www.karger.com/crg }\end{array}$ \\
\hline
\end{tabular}

\section{Discussion}

The frequency of heterotopic gastric mucosa is different depending on the examinations employed. According to Yamagiwa et al. [8], heterotopic pancreas was present in 107 cases among the 5,446 surgically resected stomachs, the incidence being $1.2 \%$. This incidence may be correct, because they examined the whole stomach by numerous sections [8]. Shi et al. [14] found only 1 case of gastric heterotopic pancreas in 7 years in their large hospital. Tanaka et al. [15] found that only 2 cases of heterotopic pancreas $(0.03 \%)$ were present in the stomach in 22 years in their University Hospital. Pang [1] experienced only 3 cases of gastric heterotopic pancreas in 10 years in his large hospital. In the present study, 3 cases with heterotopic pancreatic tissue were identified among the 8,154 gastric specimens; the frequency was $0.04 \%$. In the present report, only biopsies and only extremely small parts of gastrectomies were examined. Therefore, the frequency was very low, compared to the whole stomach examination by Yamagiwa et al. [8]. Thus, the difference may be due to the fact that the present report contains biopsy cases and the fact that only very small parts of gastrectomied specimens were examined in the present study.

Recently, several case reports of heterotopic pancreas with cystic changes have been published [3-7]. The present case 1 corresponds to such a case. In the present case 1, cystic changes and hemorrhage were recognized in the heterotopic pancreatic tissue. These changes may have caused epigastralgia. In the present cases 1 and 2, the heterotopic pancreatic tissue was an incidental finding in a healthy person. In case 1, the heterotopic pancreatic tissue was composed of acinar cells, ductal cells, and Langerhans islets (Heinrich type I), while in cases 2 and 3, the heterotopic pancreatic tissue consisted of acinar cells and ducts (Heinrich type II). In all cases of the present study, immunohistochemistry demonstrated no p53 mutations and very low proliferative activity, indicating that the pancreatic tissues were not neoplasms.

The histogenesis of heterotopic pancreatic tissue is controversial. In my opinion, the present first case is a true heterotopic pancreas of congenital abnormality. The second and third cases seem to be heterotopic pancreatic tissues of congenital anomalies. Yamagiwa et al. [9] suggested that Heinrich type I heterotopic pancreas of the stomach was caused by immigration from fetal pancreas, while Heinrich type II and III heterotopic pancreas arises through erroneous differentiation of primitive gastric mucosal epithelium. However, their hypothesis lacks evidence.

On the other hand, there have been several comprehensive reports of pancreatic acinar metaplasia of the stomach and liver [16-20]. The pancreatic acinar metaplastic cells were immunoreactive for pancreatic digestive enzyme. However, the authors reported that normal gastric epithelium was positive for pancreatic digestive enzyme by Western blotting, immunohistochemistry, enzyme assay, and reverse transcriptase PCR techniques [21]. In the present review of 8,154 gastric specimens, the author did not find the abnormal cells of pancreatic acinar metaplasia. In addition, the author did not detect pancreatic acinar metaplasia. There is lack of evidence that pancreatic acinar metaplasia in the stomach is true metaplasia. An investigation of fetal organogenesis is mandatory for pancreatic acinar metaplasia.

The author previously investigated heterotopic pancreatic tissue of consecutive 1,000 autopsy livers of different age groups, and identified 50 cases (5\%) of minute heterotopic 
pancreatic acinar tissues positive for pancreatic digestive enzymes and zymogen granules [2]. All of them were composed of acinar cells with or without ductal elements [2]. No islets were recognized [2]. Further, the author investigated the fetal development of intrahepatic bile ducts [22-27], and discovered that intrahepatic bile ducts frequently differentiated into pancreatic acinar cells in the fetal period. These observations highly suggest that clusters of pancreatic acinar cells are congenital in origin. 


\begin{tabular}{c|l|l|l}
$\begin{array}{r}\text { Case Reports in } \\
\text { Gastroenterology }\end{array}$ & $\begin{array}{l}\text { Case Rep Gastroenterol 2010;4:386-392 } \\
\text { DOl: 10.1159/000320676 }\end{array}$ & $\begin{array}{l}\text { Published online: } \\
\text { September 18, 2010 }\end{array}$ & $\begin{array}{l}\text { O 2010 S. Karger AG, Basel } \\
\text { ISSN 162--0631 } \\
\text { www.karger.com/crg }\end{array}$ \\
\hline
\end{tabular}
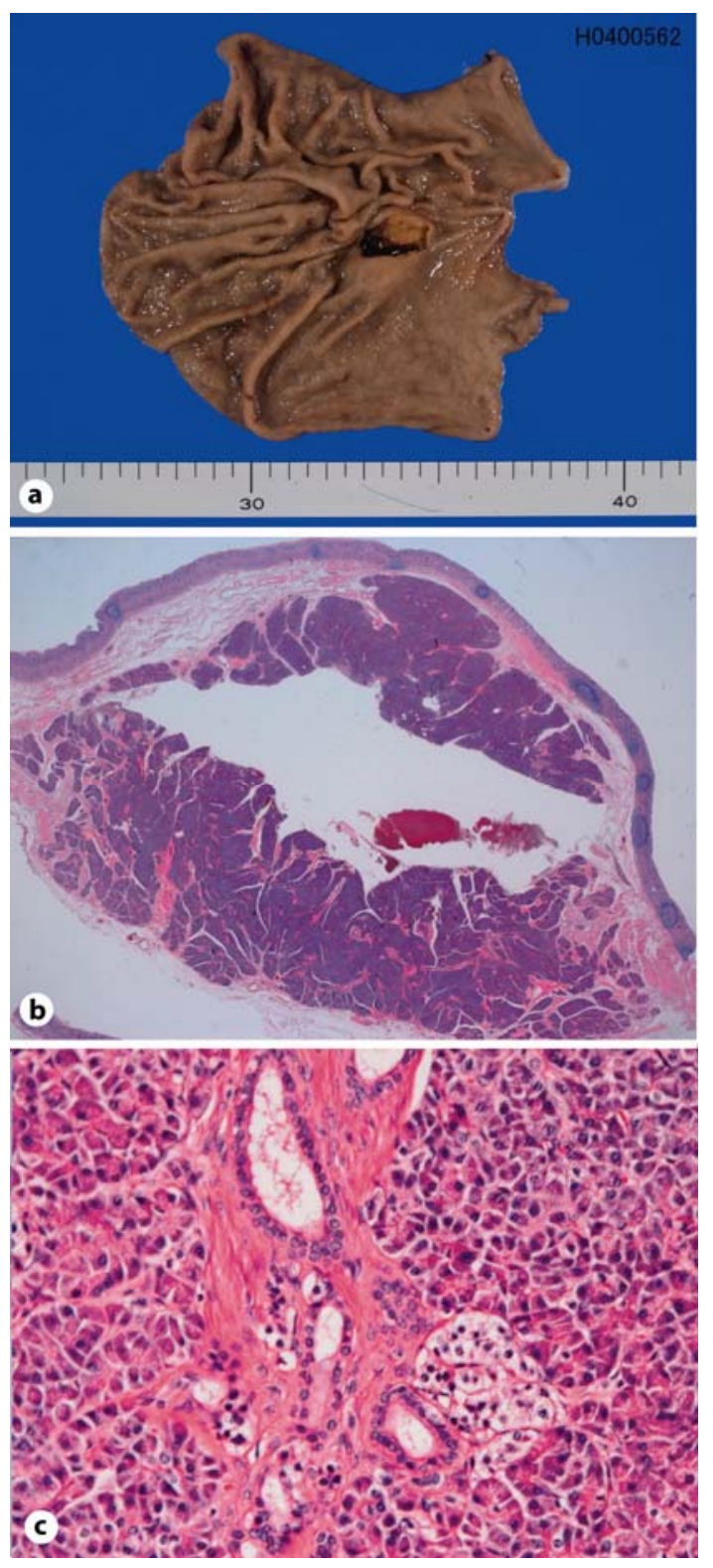

Fig. 1. Case 1. a Grossly, a submucosal tumor of heterotopic pancreas is seen in the center of the resected stomach. $\mathbf{b}$ Histology shows heterotopic pancreas with cystic changes and hemorrhage. c The hererotopic pancreas contains acinar cells, ducts, and islet. HE, $\times 200$. 


\begin{tabular}{r|l|l|l}
$\begin{array}{c}\text { Case Reports in } \\
\text { Gastruanteriology }\end{array}$ & $\begin{array}{l}\text { Case Rep Gastroenterol 2010;4:386-392 } \\
\text { DOI: 10.1159/000320676 }\end{array}$ & $\begin{array}{l}\text { Published online: } \\
\text { September 18, 2010 }\end{array}$ & $\begin{array}{l}\text { O 2010 S. Karger AG, Basel } \\
\text { ISSN 1662-0631 } \\
\text { www.karger.com/crg }\end{array}$ \\
\hline
\end{tabular}
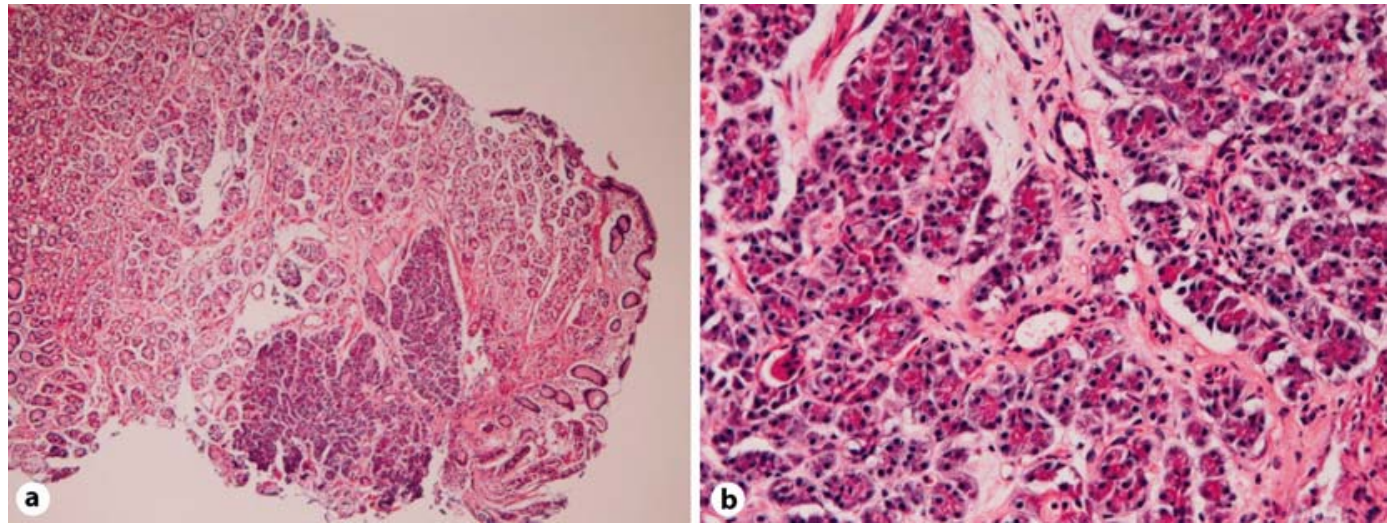

Fig. 2. Case 2. a Low-power view of the heterotopic pancreatic tissue in gastric biopsy. HE, $\times 40 . \mathbf{b}$ The heterotopic pancreatic tissue shows acinar cells and ductal elements. HE, $\times 200$.
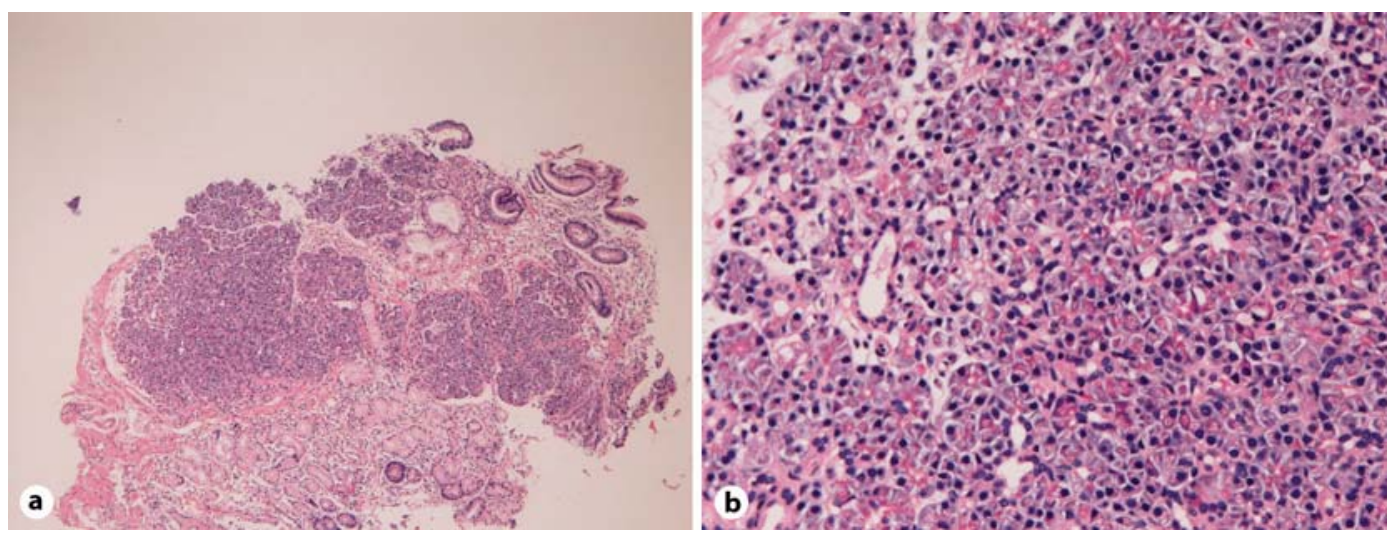

Fig. 3. Case 3. a Low-power view of the heterotopic pancreatic tissue in gastric biopsy. HE, $\times 40$. $\mathbf{b}$ The heterotopic pancreatic tissue contains acinar cells and ductal elements. HE, $\times 200$.

\section{References}

1 Pang LC: Pancreatic heterotopia: a reappraisal and clinicopathologic analysis of 32 cases. South Med J 1988;81:1264-1275.

2 Terada T, Nakanuma Y, Kakita A: Pathologic observations of intrahepatic peribiliary glands in 1,000 consecutive autopsy livers: heterotopic pancreas in the liver. Gastroenterology 1990;98:1333-1337.

-3 Chiristodoulidis G, Zacharoulis D, Barbanis S, Katsogridakis E, Harzithefilou K: Heterotopic pancreas in the stomach: a case report and literature review. World J Gastroenterol 2007;13:6098-6100.

-4 Yen HH, Soon MS, Soon A: Heterotopic pancreas presenting gastric submucosal cyst on endoscopic sonography. J Clin Ultrasound 2006;34:203-206.

5 Rubbira-Brandt L, Huber O, Hadengue A, Frossard JL: An unusual case of gastric heterotopic pancreas. JOP 2004;5:484-489.

6 Yamashita K, Yamazaki K, Ueno A, Arimura Y, Endo T, Imai K: Image of the month: a gastric heterotopic pancreas with cystic change. Gastroenterology 2005;129:1374.

-7 Lopez-Pelaez MS, Hoyos FB, Isidro MG, Unzurrunzaga EA, Lopez Ede V, Collazo YQ: Cystic dystrophy of heterotopic pancreas in stomach: radiologic and pathologic correlation. Abdom Imaging 2008;33:391-394. 
8 Yamagiwa H, Ishihara A, Sekoguchi T, Matsuzaki O: Heterotopic pancreas in surgically resected stomach. Gastroenterol Jpn 1977;12:380-386.

-9 Yamagiwa H, Onishi N, Nishi M: Heterotopic pancreas of the stomach: histogenesis and immunohistochemistry. Acta Pathol Jpn 1992;42:249-254.

10 Terada T, Kawaguchi M, Furukawa K, Sekido Y, Osamura Y: Minute mixed ductal-endocrine carcinoma of the pancreas with predominant intraductal growth. Pathol Int 2002;52:740-746.

-11 Terada T: Primary multiple extragastrointestinal stromal tumors of the omentum with different mutations of c-kit gene. World J Gastroenterol 2008;14:7256-7259.

12 Terada T: Gastrointestinal stromal tumor of the uterus: a case report with genetic analyses of c-kit and PDGFRA genes. Int J Gynecol Pathol 2009;28:29-34.

13 Terada T: Large endocervical polyp with cartilaginous and osseous metaplasia: a hitherto unreported entity. Int J Gynecol Pathol 2009;28:98-100.

14 Shi HQ, Zhang QY, Teng HL, Chen JC: Heterotopic pancreas: report of 7 patients. Hepatobiliary Pancreat Dis Int 2002;1:299-301.

-15 Tanaka K, Tsunoda T, Eto T, Yamada M, Tajima Y, Shimogawa H, Yamaguchi T, Matsuo S, Izawa K: Diagnosis and management of heterotopic pancreas. Int Surg 1993;78:32-35.

-16 Wolf HK, Burchette JL Jr, Garcia JA, Michalopoulos G: Exocrine pancreatic tissue in human liver, a metaplastic process? Am J Surg Pathol 1990;14:590-595.

-17 Doglioni C, Laurino L, Del Tos AP, De Boni M, Franzin G, Braidotti P, Viale G: Pancreatic (acinar) metaplasia of the gastric mucosa: histology, ultrastructure, immunohistochemistry, and clinicopathologic correlations of 101 cases. Am J Surg Pathol 1993;17:1134-1143.

18 Integlia MJ, Krishnamurthy S, Berhane R, Grand RJ, Dayal Y: Pancreatic metaplasia of the gastric mucosa in pediatric patients. Am J Gastroenterol 1997;92:1553-1556.

-19 Krishnamurthy S, Integlia MJ, Grand RJ, Dayal Y: Pancreatic acinar cell clusters in pediatric gastric mucosa. Am J Surg Pathol 1998;22:100-105.

20 Jhala NC, Montemor M, Jhala D, Lu L, Talley L, Harber MM, Lechago J: Pancreatic acinar metaplasia in autoimmune gastritis. Arch Pathol Lab Med 2003;127:854-857.

-21 Terada T, Kitamura Y, Ashida K, Matsunaga Y, Ohta T: Expression of pancreatic digestive enzymes in normal and pathologic epithelial cells of the human gastrointestinal system. Virchows Arch 1997;431:195-203.

-22 Terada T, Nakanuma Y: Development of human intrahepatic peribiliary glands: histological, keratin immunohistochemical and mucus histochemical analyses. Lab Invest 1993;68:261-269.

23 Terada T, Nakanuma Y: Development of human peribiliary capillary plexus: A lectin-histochemical and immunohistochemical study. Hepatology 1993;18:529-536.

-24 Terada T, Nakanuma Y: Profiles of expression of carbohydrate chain structures during human intrahepatic bile duct development and maturation: a lectin-histochemical and immunohistochemical study. Hepatology 1994;20:388-397.

25 Terada T, Nakanuma Y: Detection of apoptosis and expression of apoptosis-related proteins during human intrahepatic bile duct development. Am J Pathol 1995;146:67-74.

26 Terada T, Nakanuma Y: Expression of pancreatic enzymes ( $\alpha$-amylase, trypsinogen and lipase) during human liver development and maturation. Gastroenterology 1995;108:1236-1245.

27 Terada T, Okada Y, Nakanuma Y: Expression of matrix proteinases during human intrahepatic bile duct development: a possible role in biliary cell migration. Am J Pathol 1995;147:1207-1213. 